\title{
POWDERY FORMULATION OF ESSENTIAL OILS FOR THE CONTROL OF RICE WEEVIL SITOPHILUS ORYZAE L. (COLEOPTERA: CURCULIONIDAE)
}

\author{
TAMGNO $^{1 *}$, Béranger Raoul; NGAMO TINKEU ${ }^{2}$, Léonard Simon; DJIETO-LORDON ${ }^{3}$, Champlain and \\ NGASSOUM ${ }^{4}$, Martin Benoit \\ ${ }^{1}$ Institute of Fisheries and Aquatic Sciences, the University of Douala, P.0.Box 7236; Douala, Cameroon. \\ ${ }^{2}$ Faculty of Science, the University of Ngaoundéré, P.O. Box 454, Ngaoundéré, Cameroon. \\ ${ }^{3}$ Faculty of Science, the University of Yaoundé I, P.O. Box 812, Yaoundé, Cameroon. \\ ${ }^{4}$ National Higher Advanced School of Agro-industrial Sciences, University of Ngaoundéré P.O. Box 455, \\ Ngaoundéré, Cameroon. \\ http://doi.org/10.35410/IJAEB.2019.2436
}

\begin{abstract}
In spite of the effectiveness of the essentials oils and flour of leguminous seeds against insect attacks, they are less attractive to producers that continue to use chemicals that have potential adverse effects on consumers and the ecosystems through pollution. The present research was carried out to evaluate insecticidal properties of powdery formulations of essential oils of 3 plants: leaves of Eucalyptus citriodora (Myrtaceae), dried fruits of Xylopia aethiopica (Dunal) A. Richard (Annonaceae) and the roots of Echinops giganteus var. lelyi C.D Adams (Asteraceae) with seeds of black bean on Sitophilus oryzae. The toxicity by contact-inhalation of essential oils, alone or in combination, in different concentrations is evaluated against young adults of $S$. oryzae with two weeks old after 24 hours. For powdery formulation, the test of contact-ingestion and inhalation is evaluated in different doses each week during 7 weeks. The research carried out reveals that $X$. aethiopica is the most active on $S$. oryzae with the lethal doses 50 and 90 respectively 37.1 and $57 \mathrm{ppm}$. In combination, E. giganteus which alone is not insecticidal, enhance significantly the insecticidal efficiency of the 2 other essential oils. The most insecticidal powdery formulation is that of E. citriodora with $100 \%$ of mortality two weeks after the application. The present work gives evidence of the insecticidal efficiency of a powdery formulation in the protection of stored cereals from weevil attacks. This method potentially has no adverse effect on consumers and on the environment at the doses used and could be developed and popularized.
\end{abstract}

Keywords: Cereals; Essentials Oils; Black Bean; Powdery Formulation; Sitophilus oryzae.

\section{INTRODUCTION}

Many pests of stored products are Coleopterans and the most destructive tropical species for cereals belong to the genus Sitophilus and Tribolium (Tamgno, 2016, Tamgno and Ngamo Tinkeu, 2013; Nukenine et al, 2011, Ngamo Tinkeu and Hance; 2007). Damage due to Sitophilus on cereals and others cereal processed products, are mostly impurities and stains which would be able of poisoning consumers (Tamgno and Ngamo Tinkeu, 2013). The control of pests in stored cereal grains, by the application of chemicals which is a common strategy for post-harvest loss avoidance (Ngamo Tinkeu et al, 2016; Tamgno, 2016), had led to the occurrence of many 
problems like the pollution of environment, toxicity to human being, emergence of resistant pests strains and many others damages (Idrissi et al, 2010, Regnault-Roger et al, 2008, Glitho et al, 2008). The liberalization of this sector of chemicals has permitted the circulation of the illicit and obsolete synthetic insecticides (Tamgno, 2016, Ngamo Tinkeu et al, 2016). These synthetic pesticides are expensive for the small-scale farmers and pose potential risks due to the lack of technical knowledge on their safe use.

Due to the hazardous effects of chemicals on the environment, human health and useful organisms, the Montreal Protocol recommended their withdrawal from the market in 2010. About 10 years after, few alternative products are proposed in post-harvest grain protection by science to ensure this withdrawal. Recent researches have been undertaken in order to minimize the agro-environmental pollution and health hazards caused by them and to replace them with other methods (Tamgno et Ngamo Tinkeu, 2018, Ngamo Tinkeu et al, 2016, Mebarkia et al, 2012, Folefack et al, 2013, Nguemtchouin Mbouga, 2012, Nukenine et al, 2011, Karimi et al, 2010, Goudoum et al, 2010, Faye, 2010). Hence, there is need to explore new effective biological pests control methods like insecticides based on aromatic plants by essential oils and entomotoxic proteins obtained from legumes which can confer protection to plants against insect pests (Tamgno and Ngamo Tinkeu, 2018, Ngamo Tinkeu et al, 2016, Tamgno, 2016, Nguemtchouin Mbouga, 2012, Goudoum, 2010, Ngamo Tinkeu et al, 2007).

The most efficient crop protection method nowadays must be one which employs a consumerand environmentally-friendly approach.

The use of protecting materials which are edible by human and other animals may be a good alternative in pest control. The bio assays on the insecticidal efficacy of crude essential oils of aromatic plants have been explored; but these insecticides are less attractive for producers because of their high volatilization and low persistence (Nguemtchouin Mbouga, 2012, Kouninki et al, 2007, Ngamo Tinkeu et al, 2007). For these reasons, there is therefore a need to formulate them as an easy handling chemical with better persistence. The use of flour of legume seeds that their insecticidal efficacy has been established like support of essential oils can ameliorate their persistence (Tamgno, 2016, Ngamo Tinkeu et al, 2016, Tamgno and Ngamo Tinkeu, 2014, Mebarkia et al, 2012, Fatimé, 2007).

The objective of this study was to determine the sensitivity of the rice weevil Sitophilus oryzae adults to the insecticidal properties of crude essential oils of Eucalyptus citriodora (Myrtaceae), Echipnos giganteus (Asteraceae) and Xylopia aethiopica Dunal A. Rich (Annonaceae) in formulation with the flour of Phaseolus vulgaris by contact -inhalation and contact-ingestion.

\section{MATERIALS AND METHODS}

\subsection{Insect used and its rearing}

The millet weevil Sitophilus oryzae was used at adult stage. They were obtained from the Unity of Entomological Researches (UER) of the University of Ngaoundéré (Adamaoua-Cameroon) where a permanent rearing is kept in the dark in incubators at $27 \pm 2.1{ }^{\circ} \mathrm{C}$. The millet weevil belonged to the strain collected in November 2003 in the granary of a peasant at Beka Hosséré 
(Ngaoundéré). For the experiments, adults of $S$. oryzae used were two weeks old. Before being tested, these insects were starved for a 24 hours period.

\subsection{Origin and preparation of the flour of seeds of Phaseolus vulgaris}

The seeds of little black bean Phaseolus vulgaris coming from Bandjoun in West Region of Cameroon were reduced to flour in the UER. $500 \mathrm{~g}$ have been ground using a mill, type WARRING BLENDOR to obtain the flour. Flours obtained were sifted using a sieve, type RETSCH GmbH \& Co D-42781, of mesh-size lower than $0.5 \mathrm{~mm}$ : the big particles were eliminated. The flour obtained was weighed using a SARTORIUS balance, type 126400 with precision of $0.01 \mathrm{~g}$. One part of flours was used directly for biological assays and the rest kept for the preparation with essential oils.

\subsection{Aromatic plants collection and hydro distillation}

Three parts of three aromatic plants were used for this study: leaves of Eucalyptus citriodora (Myrtaceae), dried fruits of Xylopia aethiopica (Dunal) A. Richard (Annonaceae) and the roots of Echinops giganteus var. lelyi C.D Adams (Asteraceae). Leaves of E. citriodora were collected in Onaref quarter in Ngaoudéré near the point referenced $14^{\circ} 24.145^{\prime} \mathrm{E}$ longitude, $07^{\circ} 39.214^{\prime} \mathrm{N}$ latitude Nord and the altitude $1375 \mathrm{~m}$. Roots of E. giganteus were harvested in the guinean savannah of Bini-Dang, Ngaoundéré referenced by $13^{\circ} 32.272^{\prime} \mathrm{E}$ longitude, $07^{\circ} 24.330^{\prime} \mathrm{N}$ latitude and $1293 \mathrm{~m}$ altitude. The dried fruits of $X$. aethiopica were bought in Mbitom market (Adamaoua-Cameroon). These data were collected with a GPS Garmin Geko 301.

In laboratory before hydro distillation, the leaves were dried at shadow far from sunlight in the laboratory conditions during three days; the roots were washed and cut as fruits in pieces; each part was weighed. The extraction of essential oils of each aromatic plant was carried out in a Clevenger-type apparatus during $4 \mathrm{~h}$. The essential oils obtained were put in the flasks and kept in the refrigerator at $4^{\circ} \mathrm{C}$ till their use in bioassays.

\subsection{Formulation of Xylopia aethiopica and Eucalyptus citriodora essential oils with flour of Phaseolus vulgaris for contact-ingestion toxicity tests}

The lethal doses $100\left(\mathrm{LD}_{100}\right)$ essential oils of $X$. aethiopica $(80 \mu \mathrm{l})$ or E. citriodora $(160 \mu \mathrm{l})$ were formulated as powder using various proportions $(1 \mathrm{~g}, 5 \mathrm{~g}$ and $10 \mathrm{~g})$ of black bean (BB) flour $(P$. vulgaris) according to a $\mathrm{LD}_{100}$ of black bean (BB) flour (10 g) on $S$. oryzae (Tamgno, 2016, Tamgno and Ngamo Tinkeu, 2018). Six treatments were made: BB01X, BB05X and BB10X for $X$. aethiopica and $\mathrm{BB} 01 \mathrm{E}, \mathrm{BB} 05 \mathrm{E}$ and $\mathrm{BB} 10 \mathrm{E}$ for E. citriodora. After homogenizing with spatula, two aromatized flours were obtained: one with $X$. aethiopica and the other one with $E$. citriodora, and directly used for bioassays.

\subsection{Biological tests}

\subsubsection{Evaluation of insecticidal efficiency of crude essential oils}

The evaluation was done by contact-inhalation. A micropipette was used to remove $50 \mu 1,100$ $\mu \mathrm{l}, 150 \mu \mathrm{l}, 200 \mu \mathrm{l}$ and $250 \mu \mathrm{l}$ of each essential oil and diluted it in $2.5 \mathrm{ml}$ acetone to formulate 
insecticides. For each preparation, $0.5 \mathrm{ml}$ was pumped and flowed regularly on a disk of filter paper (Wathmann $\mathrm{n}^{\circ} 1$ ) of $9 \mathrm{~cm}$ diameter placed in a Petri dish. The dish was finally covered; a control with acetone alone, without essential oil was done. This permit to obtain the following concentrations: 125 ppm, 250 ppm, 375 ppm, 500 ppm and 625 ppm by dish. After this, 20 insects were introduced in each dish 4 min later. The dish was finally covered; a control with acetone alone, without essential oil was done. For each preparation, 4 replications were carried out. The amount of death insects was counted $24 \mathrm{~h}$ after the application.

\subsubsection{Determination of lethal doses 50 and $90\left(\mathrm{LD}_{50}\right.$ and $\left.\mathrm{LD}_{90}\right)$ of essential oils of Xylopia aethiopica and Eucalyptus citriodora}

These experiments aimed to establish the lethal doses 50 and 90 (LD LD $_{50}$ and LD90) of essential oils of $X$. aethiopica and E. citriodora. With a micropipette (Rainin Magnetic-assist), 8 volumes of $E$. citriodora 20, 40, 60, 80, 100, 120, 140 and $160 \mu 1$ and 4 volumes of $X$. aethiopica 20, 40, 60 and $80 \mu \mathrm{l}$ were pumped and each volume was diluted into $2.5 \mathrm{ml}$ of acetone. For each preparation, $0.5 \mathrm{ml}$ was pumped and flowed regularly on a disk of filter paper (Wathmann $\mathrm{n}^{\circ} 1$ ) of $9 \mathrm{~cm}$ diameter placed in a Petri dish. After this, 20 insects were introduced in each dish $4 \mathrm{~min}$ later. The dish was finally covered; a control with acetone alone, without essential oil was done. For each preparation, 4 replications were carried out. The amount of death insects was counted $24 \mathrm{~h}$ after the application.

\subsubsection{Toxicity of powdery formulation with the essential oils of Xylopia aethiopica,} Eucalyptus citriodora and flour of Phaseolus vulgaris

In the pots in glass of $1800 \mathrm{ml}$ of capacity containing 99, 95 and $90 \mathrm{~g}$ of sorghum grains, 1, 5 and $10 \mathrm{~g}$ of each aromatized flours were added respectively in sort that each pot had $100 \mathrm{~g}$ of content. The content of each pot was homogenized by stirring it 20 times using a spatula. Six treatments without control were made. The pots that contain only the sorghum grains constitute the control. 20 young adults of $S$. oryzae were introduced in theses pots for rearing. After each week on 7 weeks, all the pots were checked; the amounts of dead adults were evaluated. For each preparation, 5 replications were made.

\subsection{Statistical analysis}

Data on mortalities of this insect considered were subjected to one-way variant analysis (ANOVA I) in the aim to determine the most insecticidal formulations of essential oils and black beans' flour. To complete this analysis, the Duncan's multiple range test (DMRT) was used to group together the mean values that are not significantly different.

\section{RESULTS}

3.1. Insecticidal efficacy of essential oils of Xylopia aethiopica, Eucalyptus citriodora and Echinops giganteus on Sitophilus oryzae alone and in equal combinations

In the control $(0 \mathrm{ppm})$, no mortality is observed. Similarly, for all the concentrations tested, the essential oil of E. giganteus does not induce any mortality; this essential oil therefore has no insecticidal property on $S$. oryzae for the doses tested. On the other hand, the essential oils of $X$. 
aethiopica and E. citriodora taken alone, show, to varying levels, insecticidal properties on $S$. oryzae (Table 1).

Table 1. Insecticidal activity of the three essential oils Xylopia aethiopica, Eucalyptus citriodora and Echinops giganteus and their combinations towards Sitophilus oryzae

\begin{tabular}{ccccccc}
\hline $\begin{array}{c}\text { Essential oils } \\
\text { Doses (ppm) }\end{array}$ & $X . a$ & $E . c$ & $E . g$ & $X . a+E . c$ & $X . a+E . g$ & $E . c+E . g$ \\
\hline 0 & $0 \pm 0^{\mathrm{f}}$ & $0 \pm 0^{\mathrm{f}}$ & $0 \pm 0^{\mathrm{f}}$ & $0 \pm 0^{\mathrm{f}}$ & $0 \pm 0^{\mathrm{f}}$ & $0 \pm 0^{\mathrm{f}}$ \\
125 & $55 \pm 12.2^{\mathrm{c}}$ & $52.5 \pm 104^{\mathrm{c}}$ & $0 \pm 0^{\mathrm{f}}$ & $0 \pm 0^{\mathrm{f}}$ & $40 \pm 10.4^{\mathrm{de}}$ & $31.25 \pm 4.8^{\mathrm{e}}$ \\
250 & $100 \pm 0^{\mathrm{a}}$ & $83.75 \pm 17.0^{\mathrm{ab}}$ & $0 \pm 0^{\mathrm{f}}$ & $53.75 \pm 4.8^{\mathrm{c}}$ & $76.25 \pm 6.3^{\mathrm{b}}$ & $76.25 \pm 7.5^{\mathrm{b}}$ \\
375 & $100 \pm 0^{\mathrm{a}}$ & $98.75 \pm 2.5^{\mathrm{a}}$ & $0 \pm 0^{\mathrm{f}}$ & $88.75^{\mathrm{a}}$ & $90 \pm 3^{\mathrm{ab}}$ & $78.75 \pm 4.8^{\mathrm{ab}}$ \\
500 & $100 \pm 0^{\mathrm{a}}$ & $100 \pm 0^{\mathrm{a}}$ & $0 \pm 0^{\mathrm{f}}$ & $100 \pm 0^{\mathrm{a}}$ & $100 \pm 0^{\mathrm{a}}$ & $80 \pm 0^{\mathrm{ab}}$ \\
625 & $100 \pm 0^{\mathrm{a}}$ & $100 \pm 0^{\mathrm{a}}$ & $0 \pm 0^{\mathrm{f}}$ & $100 \pm 0^{\mathrm{a}}$ & $100 \pm 0^{\mathrm{a}}$ & $100 \pm 0^{\mathrm{a}}$ \\
\hline $\mathrm{F}(108 ; 35)$ & & $236.384^{*} * *$ & &
\end{tabular}

The mortality values followed by the same letter do not different significantly, $p \leq 0.001$; Legends : X. a : Xylopia aethiopica ; E. c: Eucalyptus citriodora et E. g: Echinops giganteus

It appears that the effectiveness of insecticidal properties of essential oils varies depending on the plant species, the dose used and the combinations made. The results confirm the toxicity of the essential oils of E. citriodora and $X$. aethiopica alone, and that of the combination of $X$. aethiopica + E. giganteus, E. citriodora $+X$. aethiopica and E. citriodora + E. giganteus on $S$. oryzae; but this toxicity varies according to the essential oils and their combinations.

At the $125 \mathrm{ppm}$ dose, the ANOVA I shows there is a very highly significant difference between the mortalities induced by the essential oils of E. citriodora $+X$. aethiopica and X. aethiopica + $E$. giganteus on the one hand, and between the ones of $X$. aethiopica $+E$. giganteus and $E$. citriodora + E. giganteus on the other hand. Except this dose, a comparison by ANOVA I shows no significant difference between the different balanced combinations (Table 1). Although the mortalities induced by the $250 \mathrm{ppm}$ to $625 \mathrm{ppm}$ doses of the essential oils separately are high than those of the mixtures, the ANOVA I does not indicate any difference. As the control treatment, the mixture E. citriodora $+X$. aethiopica does not induce mortality at $125 \mathrm{ppm}$. The mixture $X$. aethiopica $+E$. giganteus is more effective than the mixture E. citriodora+ $X$. aethiopica which is also more insecticidal than E. citriodora + E. giganteus. 
For all combinations made, it appears a negative interaction between the constituents of the essential oils put together. The phenomenon of synergy is not observed for $X$. aethiopica $+E$. giganteus and E. citriodora $+E$. giganteus mixtures; this suggests that the essential oils of $X$. aethiopica and E. citriodora would be very rich in antagonistic compounds. At doses 125 and $250 \mathrm{ppm}$, the essential oil of $X$. aethiopica induces respectively 55\% and $100 \%$ of mortality whereas that of E. citriodora induces a mortality of $52 \%$ and $83.75 \%$, the mortality of $100 \%$ is being obtained only from concentrations of $500 \mathrm{ppm}$. Although the Duncan test does not show a significant difference at $1 \%$ for the doses used between these two products; these results show that the essential oil of $X$. aethiopica has a stronger insecticidal potential than that of $E$. citriodora (Table 1).

3.2. Expression of the insecticidal efficiency of the two essential oils towards Sitophilus oryzae by the estimation of their $\mathrm{LD}_{50}$ and $\mathrm{LD}_{90}$

The essential oil of $X$. aethiopica is more effective with $\mathrm{LD}_{50}$ and $\mathrm{LD}_{90}$ respectively equal to 37.1 and 53 ppm than that of E. citriodora with $\mathrm{LD}_{50}$ and LD 90 respectively of 57.4 and 112.8 (Table 2).

Table 2. Expression of the insecticidal efficiency of the essential oils of Eucalyptus citriodora and Xylopia aethiopica towards Sitophilus oryzae by the estimation of their LD 50 and LD90

\begin{tabular}{lccccc}
\hline & $\mathrm{LD}_{50}(\mathrm{ppm})$ & $\mathrm{LD}_{90}(\mathrm{ppm})$ & Equation of Regression & correlation & $\mathrm{df}$ \\
\cline { 2 - 5 } E. citriodora & $57.4^{\mathrm{a}}$ & $112.8^{\mathrm{a}}$ & $\mathrm{y}=0.0231 \mathrm{x}+3.6732$ & $0.9^{* * *}$ & 7 \\
X. aethiopica & $37.1^{\mathrm{b}}$ & $53^{\mathrm{b}}$ & $\mathrm{y}=0.0804 \mathrm{x}+2.02$ & $0.98^{* * *}$ & 3
\end{tabular}
0.001).

In the same colon, the letter affected by the same letter do not different significantly ( $p \leq$

Moreover, the statistical analysis between the different $\mathrm{LD}_{50}$ and $\mathrm{LD}_{90}$ shows a very highly significant difference between the two essential oils. The origin of these variations of efficiency between the essential oils can be explained by the difference in the chemical composition of the different plant species. For these essential oils of $X$. aethiopica and E. giganteus, the correlation is strong and positive between the induced mortalities and the doses of essential oils $(\mathrm{r}=0,9 * * *)$.

\subsection{Effects of Xylopia aethiopica and Eucalyptus citriodora essential oils formulated with flour of black beans on Sitophilus oryzae}

The different treatments have insecticidal properties, and the toxicity of the different formulations on $S$. oryzae varies according to the proportions of black bean meal, the essential oil and the duration of exposure. BB01E treatment induces almost $100 \%$ of mortality compared to $73 \%$ of mortality induced by BB01X treatment at the end of the same first week of exposure (Figures 1, 2). 


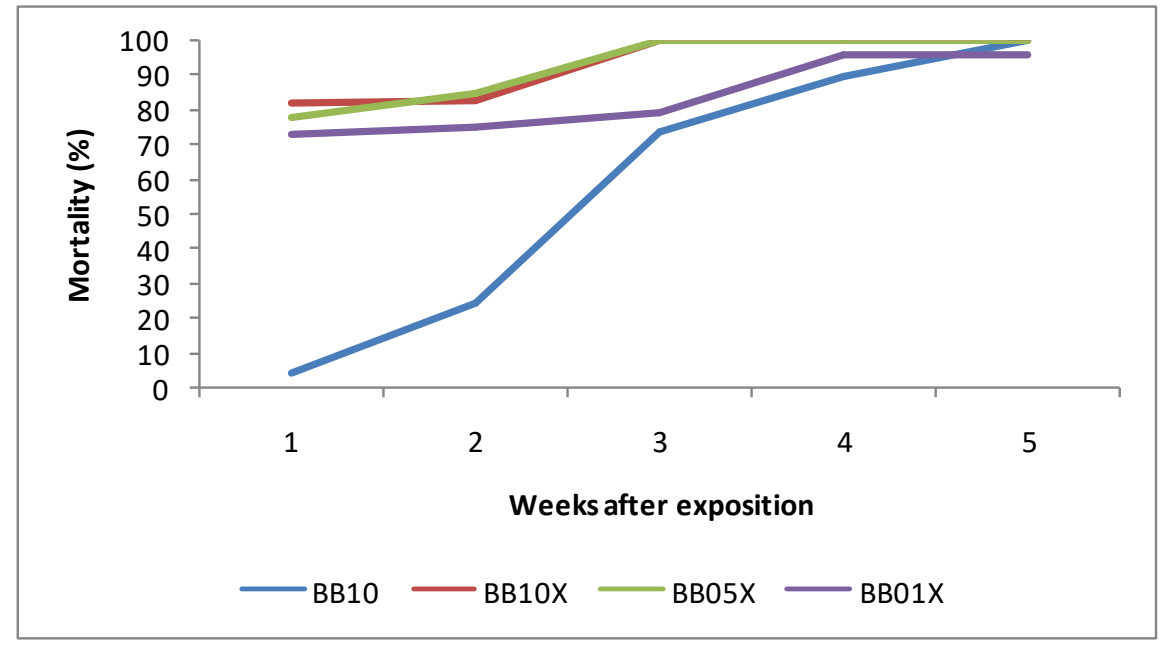

Legends: BB10: Black bean at $10 \mathrm{~g}, B B 10 X, B B 05 X$ and BB01X: Black bean at 10, 5 and $1 \mathrm{~g}$ formulated with the essential oil of $X$. aethiopica

Figure 1. Mortalities of Sitophilus oryzae by contact -inhalation and ingestion of aromatized flours with Xylopia aethiopica

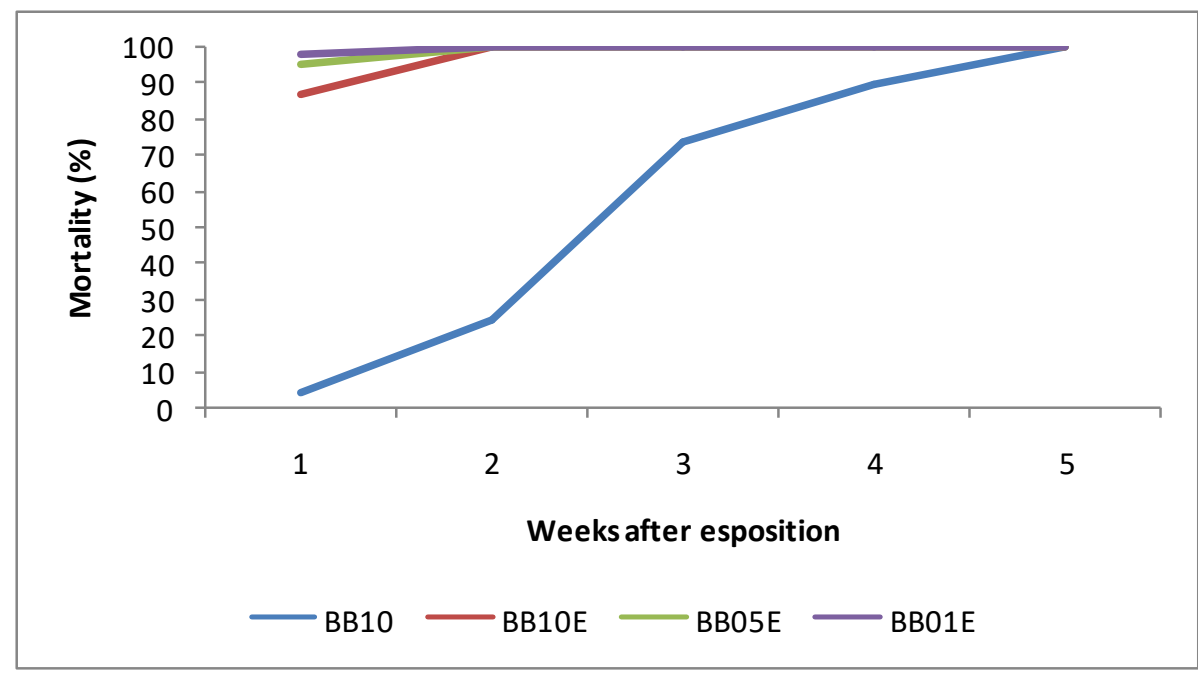

Legends: BB10: Black bean at $10 \mathrm{~g}$, BB10E, BB05E and BB01E: Black bean at 10, 5 and $1 \mathrm{~g}$ formulated with the essential oil of E. citriodora

Figure 2. Mortalities of Sitophilus oryzae by contact -inhalation and ingestion of aromatized flours with Eucalyptus citriodora 
The comparison of the results obtained with the different formulations shows that those based on the essential oil of E. citriodora are more toxic than those based on $X$. aethiopica. Indeed, the $\chi^{2}$ test shows that there is a statistically significant difference $(\mathrm{p} \leq 0.05)$ between the mortalities induced by these 2 groups of formulation 2 weeks after infestation for treatments BB10X and $\mathrm{BB} 10 \mathrm{E}, \mathrm{BB} 05 \mathrm{X}$ and $\mathrm{BB} 05 \mathrm{E}$ of a part and 3 weeks after infestation for treatments BB01X and BB01E (Table 3).

It should also be noted that treatments BB10E, BB05E and BB01E induce 100\% mortality 2 weeks after infestation, whereas this rate is reached with BB10X and BB05X only after four weeks (Figures 1,2). At this time, treatment BB01X induces 96\% mortality. In acute toxicity tests, the essential oil of $X$. aethiopica was found to be more toxic than that of E. citriodora (Tables 1,2). After the first week, the $\chi^{2}$ value shows there is no difference between mortality rates induced by the treatments $\mathrm{BB} 10 \mathrm{E}$ and $\mathrm{BB} 10 \mathrm{X}\left(\chi^{2}=5 \mathrm{~ns}\right)$; on contrary, the difference is very highly significant between $\left(\chi^{2}=94 * * *\right)$ the other treatments except BB05E and BB05X $\left(\chi^{2}=17 *\right)$ (Table 3).

Table 3. Comparative values of square Khi on the mortalities rate according to weeks

\begin{tabular}{lcccccc}
\hline Weeks & $\begin{array}{l}\text { BB05 - } \\
\text { BB05E }\end{array}$ & $\begin{array}{l}\text { BB05- } \\
\text { BB05X }\end{array}$ & $\begin{array}{l}\text { BB05E- } \\
\text { BB05X }\end{array}$ & $\begin{array}{l}\text { BB10- } \\
\text { BB10E }\end{array}$ & $\begin{array}{l}\text { BB10- } \\
\text { BB10X }\end{array}$ & $\begin{array}{l}\text { BB10E- } \\
\text { BB10X }\end{array}$ \\
\hline $1 \mathrm{st}$ & $94 * * *$ & $77^{* * *}$ & $17^{*}$ & $83^{* * *}$ & $78^{* * *}$ & $5 \mathrm{~ns}$ \\
$2 \mathrm{nd}$ & $81^{* * *}$ & $66^{* * *}$ & $15^{*}$ & $78^{* * *}$ & $61^{* * *}$ & $17 *$ \\
$3 \mathrm{rd}$ & $36^{* *}$ & $36^{* *}$ & $0 \mathrm{~ns}$ & $26^{* *}$ & $26^{* *}$ & $0 \mathrm{~ns}$ \\
$4 \mathrm{th}$ & $14^{* *}$ & $14^{*}$ & $0 \mathrm{~ns}$ & $10 \mathrm{~ns}$ & $10 \mathrm{~ns}$ & $0 \mathrm{~ns}$ \\
$5 \mathrm{th}$ & $0 \mathrm{~ns}$ & $0 \mathrm{~ns}$ & $0 \mathrm{~ns}$ & $0 \mathrm{~ns}$ & $0 \mathrm{~ns}$ & $0 \mathrm{~ns}$ \\
\hline
\end{tabular}

ns: not significant, ${ }^{*}:$ significant, ** highly significant, ***: very highly significant

At the fifth week, there is no significant difference between all the treatments. After 3 weeks, the treatments BB05E, BB05X, BB10E and BB10X induce $100 \%$ of mortality (Figures 1, 2, Table $3)$. There is the opposite effect, which suggests that there are synergists in black bean flour. ANOVA I also reveals that there is a very highly significant difference between essential oil treatments and control treatments (Table 3). A comparison between the different treatments of the same group of formulation using the Chi squared test shows that there is no statistically significant difference, that is to say that $\mathrm{BB} 01 \mathrm{E}=\mathrm{BB} 05 \mathrm{E}=\mathrm{BB} 10 \mathrm{E}$ or else $\mathrm{BB} 01 \mathrm{X}=\mathrm{BB} 05 \mathrm{X}=$ BB10X.

\section{DISCUSSIONS}

The use of chemicals poses to human health and their environment problems of persistence and undesirable effects on non-target organism and the insect pest the phenomenon of resistance. 
Nowadays, many researches demonstrate the value of utilization of natural products as the safe alternatives to control storage pest. The bioassays made in this study were principally experimental and are focused on S. oryzae, major insect pests of cereals in Cameroon. The utilization of flours of black beans' as support of essential oils for the protection of stored cereals and their persistence is important as an alternative to chemicals.

The differences observed in the insecticidal efficiency of these essential oils (Table 1) are linked to their chemical composition that the amount and the diversity of the active molecules are not the same (Kanko et al, 2018, Nguemtchouin Mbouga, 2012, Regnault-Roger et al, 2008). The absence of mortality induced by the essential oil of E. giganteus can explain by the fact that this oil is exclusively rich in sesquiterpenoids (Menut et al, 1996); or the composition of essential oils with a strong insecticidal power are monoterpenoids (Isman, 2000, Prates et al, 1998). For all combinations made, it appears a negative interaction between the constituents of the essential oils put together. Despite of the presence of the lignans mentioned in the essential oil of $E$. giganteus which are generally inactive alone, but brought into contact with other molecules whose biological effect is known and established, significantly increase their toxicity (RegnaultRoger et al, 2008, Tene et al, 2004). The phenomenon of synergy is not observed for $X$. aethiopica + E. giganteus and E. citriodora + E. giganteus mixtures; this suggests that the essential oils of $X$. aethiopica and E. citriodora would be very rich in antagonistic compounds. The mixture E. citriodora $+X$. aethiopica gives a tangible evidence of this antagonistic effect, because the mortalities observed for this mixture are much lower than those expected precisely at the $125 \mathrm{ppm}$ and $250 \mathrm{ppm}$ doses. The mixture of essential oils permits the formation of new compounds or molecules by interaction (Ngassoum et al, 2007). In fact, similar results were obtained with the combination of the essential oils of Ocimum gratissimum and L. rugosa on Sitophilus zeamais (Aoudou, 2006). These results contrary those revealed for the balanced combinations of Vepris heterophylla with Ocimum canum or Hyptis spicigera toward S. oryzae where the phenomena of synergy were observed (Ngamo Tinkeu et al, 2007). The synergy between $O$. canum and H. spicigera has increased their repellent effects (Ngassoum et al, 2007).

The difference of the $\mathrm{LD}_{50}$ and $\mathrm{LD}_{90}$ of the essential oils of $X$. aethiopica and E. citriodora towards $S$. oryzae (Table 2) would be explained by a difference in the concentration of the compounds responsible for the insecticidal effect in the two essential oils. Indeed, the chemical composition of these two essential oils is different; X. aethiopica contains $38.2 \%$ of sabinene and B-pinène and E. citriodora contains $85 \%$ of citronellal and $4.5 \%$ of citronellol (Kanko et al, 2018, Nguemtchouin Mbouga, 2012). In general, the toxicity of essential oils varies not only according to the concentrations used, but also according to the plant and animal species used (Tamgno, 2016, Lee et al, 2004, Kim et al, 2003, Taponjou et al, 2002, Pamo et al, 2002, Shaaya et al, 1997). The variability of the $\mathrm{LD}_{50}$ of several essential oils on many stored grain pests was showed (Fatimé, 2007, Aoudou, 2006).

The analysis of mortalities induced by X. aethiopica and E. citriodora essential oils formulated with flour of black beans and the control on Sitophilus oryzae (Figures 1, 2, table 3) suggests different origins. Indeed, mortalities induced by the BB10 treatment would be the result of a food poisoning whereas those of formulations that of a respiratory and digestive poison; that essential oils generally have low to very low oral toxicity (Bruneton, 1999). The advantage of these 
formulations is related to the fact that in addition to the insecticidal powers of the essential oils, the survivors of bios tests would be affected in their development cycle. In fact, some essential oils affect the life cycle by acting on female spawning, or obviously by reducing the emergence rate of the F1 generation (Kouninki et al., 2007, Belmain et al., 2001, Regnault-Roger and Hamaraoui, 1995).

Very few studies exist of the possibility of increasing the efficacy of use of essential oils in real conditions in the protection of stored products during storage. The essential oil of 0 . gratissimum losses their efficacy after 8 days on maize, but when this essential oil passes to 45 and 107 days after fixation according to the treated fractions of clay (Nguemtchouin Mbouga, 2012). In the same way, the powder of $X$. aethipica mixed with the essential oils of the same plant has the potential to give longer-term protection of grains against Callosobruchus maculatus (Kouninki et al, 2007). Lipids or others compounds present in the flour of black beans that can absorb on terpenoids and slow down increases probably the persistence of the insecticidal activity of combination of flour and essential oils on the insect pests. Another advantage of these formulations is that once the insecticidal activity of the essential oils has faded, the single flour continues the protection because it itself has entomotoxic properties.

\section{CONCLUSION}

It emerges from this present work that the essential oils of X. aethiopica and E. citridora have insecticidal properties on $S$. oryzae and that of $E$. giganteus does not have one. From combinations of essential oils, the most toxic is that between of X. aethiopica with E. giganteus. The powdery formulations with $E$. citriodora are more toxic than those of $X$. aethiopica. In view of all these results, black bean can be used both as an insecticide and as a support for essential oil in the protection of cereals. The antagonistic effect observed in the combinations of substances shows that the traditional practice of combining plants in granaries is not always beneficial. At the end of this work, powdery formulation based on the essential oils of $X$. aethiopica or $E$. citriodora and black bean flour could contribute to the subsequent protection of post-harvest cereals against insect pest attacks.

\section{AUTHOR CONTRIBUTIONS}

All the authors contribute to define the main lines of the study. LSNT, DCL and MBN have supplied the materials of study. BRT has done a realization of the study, he makes all the bioassays.

\section{CONFLICTS OF INTEREST}

The authors declare no conflict of interest.

\section{ACKNOWLEDGEMENTS}

Authors are grateful to the Laboratories of Applied Zoology and Research of Environment Chemistry and Lipochemistry of the University of Ngaoundéré. 
Vol. 4, No. 03; 2019

ISSN: $2456-8643$

\section{REFERENCES}

Aoudou, Y. (2006). Essai d'optimisation de la protection des grains de maïs contre Sitophilus zeamais Motsch (Coleoptera: Curculionidae) et Aspergillus flavus Lab $\mathrm{L}_{1}$ avec les huiles essentielles de cinq espèces végétales. Mémoire de DEA, Département des Sciences Alimentaire et Nutrition, ENSAI, Université de Ngaoundéré, 94p. + annexes.

Belmain, S.R. Neal, G.E. Ray, D.E. and P. Golop (2001). Insecticidal and Vertebrate toxicity associated with ethnobotanical used as post harvest protectants in Ghana. Food and Chemichal Toxicology $39: 287-291$.

Bruneton, J. (1999). Pharmacognosie, phytochimie, Plantes médicinales $3^{\text {ème }}$ ed., Lavoisier, Paris. $1120 \mathrm{p}$.

Fatimé, A.A. (2007). Amélioration de la conservation de la farine de sorgho par l'incorporation des huiles essentielles et de la farine de deux légumineuses alimentaires. Mémoire de DEA, ENSAI, Université de Ngaoundéré. 94 p. + annexes.

Faye, M. (2010). Nouveau procédé de fractionnement de la graine de neem (Azadirachta indica A. Juss) sénégalais: production d'un bio-pesticide d'huile et de tourteau. Thèse de Doctorat, Université de Toulouse. 267 p. + annexes

Folefack, D.P. Sobda, A.G. Tengomo, S. Boukar, O. and A. Tahirou (2013). Vulgarisation de la méthode du triple ensachage pour le stockage amélioré du niébé en zone sahélienne du Nord Cameroun: Enjeux et perceptions paysannes. Tropicultura 31 (3) :170-178.

Glitho, L.A. Ketoh, K.G. Nuto, P.Y. Amevoin, S.K. and 1. Huignard (2008). Approches non toxiques et non polluantes pour le contrôle des populations d'insectes nuisibles en Afrique du Centre et de l'Ouest. 207-217. In Regnault-Roger, C, Philogène, B.JR. et Vincent, C (éds). Biopesticide d'origine Végétale jme édition. Lavoisier, TEC \& DOC, Paris. 550 p.

Goudoum, A. (2010). Impact des huiles essentielles sur le potentiel technologique et nutritionnel des grains et farine de maiis au cours du stockage. Thèse de Doctorat, Université de Ngaoundéré. 158 p. + annexes

Goudoum, A. Ngamo Tinkeu, L.S. Ngassoum, M.B. Tatsadjieu, N.L. and C.M. Mbofung (2010). Tribolium castaneum (Coleoptera: Curculionidae) sensitivity to repetitive applications of lethal doses of imidacloprid and extracts of Clausena anisata (Rutaceae) and Plectranthus glandulosus (Lamiaceae). International Journal of Biological and Chemical Sciences 4:1242-1250.

Idrissi, M. Aït Daoud, N. Ouammi, L. Rhalem, N. Soulaymani, A. and R. Soulayman Bencheikh (2010). Intoxication aigüe par les pesticides. Données du Centre Anti Poison du Maroc (1989-2007). Toxicology Maroc 4: 5-7.

Isman, M.B. (2000). Plant essential oils for pest management. Crop Protection 19: 603- 608.

Kanko, C. Kouamé Oussou, R. Akcah, J. Boti, J.B. Seri-Kouassi, B.P. and J. Casanova (2018). Structure des composés majoritaires et Activité insecticide des huiles essentielles extraites de sept plantes aromatiques de Côte d'Ivoire. International Journal of Engineering and Applied Sciences 4(10): 27-34.

Karimi, J. Haubruge, E. and F. Francis (2010). Development of entomotoxic molecules as control agents: illustration of some protein potential uses and limits of lectins (Review). Biotechnology, Agronomy, Society and Environment 14(1): 225-241.

Kim, S.I. Roh, Y.J. Kim, H.D. Lee, S.H. and J.Y. Ahn 2003. Insecticidal activities of aromatic plant extracts and essential oil against Sitophillus oryzae and Callosobruchus chinensis. 
Vol. 4, No. 03; 2019

ISSN: $2456-8643$

Journal of Stored Products Research 39: 293-303.

Kouninki, H. Ngamo Tinkeu, L.S. Pin-shank, T. and, M.B. Ngassoum (2007). Potential uses of essential oils from local cameroonian seedlings for the control of red flour weevil Tribolium castaneum (Herbst.) (Coleoptera: Tenebrionidae). African Journal of Food, Agriculture, Nature and Development 7(5): 1-15.

Lee, B.H. Annis P.C. Tumaalii, F. and W.S. Choi (2004). Fumigant toxicity of essential oil from the Myrtaceae family and 1,8-cineole against 3 major stored-grain insects. Journal of Stored Products Research $40: 553-564$.

Mebarkia, A. Benkohila, H.S. Hamza M. and M. Makhlouf (2012). Efficacité d'une protéine entomotoxique du type A1b des graines de légumineuses. Review Agriculture 3: 1-8.

Menut, C. Lamaty, G. Weyerstahl, P. Marschall, H. Seelmann, I. and P.H. Amvam Zollo (1996). Aromatic plants of tropical Central Africa. Part XXXI. Tricyclic sesquiterpenes from the root essential oil of Echinops giganteus var. lelyi C. D. Adams. Flavour Fragrance Journal 2(6): 415-421.

Ngamo Tinkeu L.S. Ngatanko, I. Ngassoum, M.B. Mapongmetsem, P.M. and T. Hance (2007). Insecticidal efficiency of essential oil of 5 aromatic plants tested both alone and in combination toward Sitophilus oryzae. Research Journal of Biological Sciences $2: 75-80$.

Ngamo Tinkeu, L.S. and T. Hance (2007). Diversité des ravageurs des denrées stockées et méthodes alternatives de lutte en milieu tropical. Tropicultura 25(4) : 215-220.

Ngamo Tinkeu, L.S. Ngatanko, I. Tamgno, B.R. Watching, D. Madou, C. Goudoum, A. and M.B. Ngassoum (2016). Extremely Hazardous and Highly Hazardous Pesticides Registered For Pests Control because of lack of Slightly Hazardous Alternatives. International Journal of Scientific Progress and Research 19(03): 140-145.

Ngamo Tinkeu, L.S. Tamgno, B.R. and M. Gandebe 2016. Bioactivity of flours of seeds of leguminous crops Pisum sativum, Phaseolus vulgaris and Glycine max used as botanical insecticides against Sitophilus oryzae Linnaeus (Coleoptera: Curculionidae) on sorghum grains. International Journal of Biological and Chemical Sciences 10(3): 919-927.

Ngassoum, M.B. Ngamo Tinkeu, L.S. Ngatanko, I. Tapondjou, L.A. Lognay, G. Malaisse, F. and T. Hance 2007. Chemical Composition, Insecticidal Effect and Repellent Activity of Essential Oils of Three Aromatic Plants, Alone and in Combination, towards Sitophilus oryzae L. (Coleoptera: Curculionidae). Natural Products Communication 2(12) : 1229 1232

Nguemtchouin Mbouga, M.G. (2012). Formulation d'insecticides en poudre par adsorption des huiles essentielles de Xylopia aethiopica et de Ocimum gratissimum sur des argiles camerounaises modifiées. Thèse de Doctorat en cotutelle, Ecole Nationale Supérieure de Chimie de Montpellier de France et Ecole Nationale Supérieure des Sciences AgroIndustrielles du Cameroun, 263p. + annexes

Nukenine, E.N. Tchiegang, C. Mekouo, A.A.T. Tofel, H.K. Adarkwa, C. Obeng-Ofori, D. and C. Adler (2011). Efficacy of Calneem derived from Ghanian neem seeds and seed oils from two locations in Cameroon against Sitophilus zeamais Mostchuslsky (Coleoptera: Curculionidae) on maize. International Journal of Tropical Insect Sciences 31 (4) : 225243.

Pamo, E.T. Tapondjou, L. Tenekeu, G. and F. Tendokeng (2002). Bioactivité de l'huile essentielle des feuilles de l'Ageratum houstonianum Mill sur les tiques (Rhipicephalus 
appendiculatus) de la chèvre naine de Guinée dans l'ouest du Cameroun. Tropicultura 20(3) :109-112.

Prates, H.T. Santos, J.P. Waqui, J.M. Fabris, J.D., Oliveira, A; Forster, J.E. and Embrapa (1998). Insecticidal activity of monoterpenes against Rhyzopertha domonica (F.) and Tribolium castaneum (Herbst). Journal of Stored Products Research 34 (4): 243-249.

Regnault-Roger, C. Hamaraoui, A. 1995. Fumigant toxic activity and reproductive inhibitory induced by monoterpenes on Acanthoscelides obtectus (Say) (Coleoptera) bruchid of kidney bean (Phaseolus vulgaris L.). Journal of Stored Products Research 31(4): 291299.

Regnault-Roger, C. Philogène, B.J.R. and C. Vincent (2008). Biopesticides d'origine végétale, 2ème édition, Lavoisier, Paris. $550 \mathrm{p}$.

Shaaya, E. Kostjukovski, M. Eilberg, J. and C. Sukprakarn (1997). Plants oils as fumigants and contact insecticides for the control of stored-product insects. Journal of Stored Products Research 33(1) : 7-15.

Tamgno, B.R. (2016). Potentiel insecticide des formulations poudreuses de quatre Légumineuses et du neemier contre les Insectes ravageurs des céréales en stockage dans la vallée du Logone, Thèse de Doctorat/Ph.D. Biologie des Organismes Animaux, Faculté des Sciences, Université de Ngaoundéré. 175 p. + annexes

Tamgno, B.R. and L.S. Ngamo Tinkeu (2018). Potentiel insecticide des formulations poudreuses à base des farines de graines de Pisum sativum et Phaseolus vulgaris avec la cendre de tiges de mil sur Sitophilus oryzae L. (Coleoptera : Curculionidae. International Journal of Biological and Chemical Sciences 12(1) : 90-100.

Tamgno, B.R. L.S. and Ngamo Tinkeu (2014). Application of the flour of four leguminous crops for the control of Tenebrionidae beetle (Tribolium castaneum - Herbst). African Journal of Food, Agriculture, Nature and Development 14(1):8474-8487.

Tamgno, B.R. and L.S. Ngamo Tinkeu (2013). Diversity of stored grain insect pests in the Logone valley, from northern Cameroon to western Chad Republic in Central Africa. Journal of Agricultural Sciences and Technology A 3(9): 724-731.

Taponjou, L.A. Adler, C. Bouda, H. and D.A. Fontem (2002). Efficacy of powder and essential oil from Chenopodium ambrosioides leaves as post-harvest grain protectants against sixstored product beetles. Journal of Stored Products Research 38: 395-402.

Tene, M. Tane, P. Sondengam, B.L. and J.D. Connolly (2004). Lignans from the roots of Echinops giganteus. Phytochemistry 65(14): 2101-2105. 